\title{
USING OF SOLAR ENERGY TO OPERATE MILLING MACHINE
}

Abd El-Salam, M. F. $M^{1}$; W. k. Mohamed ${ }^{2}$;

M. A. Baiomy ${ }^{3}$ and A. A. M. Taie ${ }^{4}$

ABSTRACT

In the present study, solar energy used to operate milling machine. The study and experiments were run at summer season 2017. Sun light is used as the sustainable source of energy. In this study, the photovoltaic system was used to operate small stationary Agricultural machine (milling machine). Photovoltaic system (PV) is semiconductor devices that convert sunlight to direct electricity (current DC). It was consisting of three main parts: 1- Solar panel station was consisting of 16 modules; each module is consisting of 60 solar cells. It was used to generate the energy that needed to operate milling machine. 2- Inverter to converts the DC voltage back to AC voltage for machine motor. 3- Switch for controlling the machine operation by turning on and off. Milling machine was operated by solar energy at different period of time from 9 am to 16 pm. Two raw materials (maize - dry bread) were used with milling machine. Solar radiation was recorded at the period of study (summer 2017). It was from 358 to $790 \mathrm{~W} . \mathrm{m}^{-2}$ and the power was resulted from $P V$ system was from 1.16 to $2.55 \mathrm{~kW}$ at period of study. The main results for milling maize and dry bread by using solar energy ( $P V$ system) were as follows:

- $\quad$ The power consumption was about 1.4 and $1.37 \mathrm{~kW}$ with maize and dry bread respectively, from $P V$ cell was given power about $1.16-2.5 \mathrm{~kW}$.

- $\quad$ The power required from PV system to operate the milling machine was from 10 am to $4 \mathrm{pm}$.

- $\quad$ The maximum productivity and power can be obtained at midday (noon). The maximum productivity was $9.09 \mathrm{~kg} . \mathrm{h}^{-1}$ and $7.5 \mathrm{~kg} . \mathrm{h}^{-1}$ with maize and dry bread.

\footnotetext{
${ }^{1}$ Assoc. Prof. of Agric. Eng. Dept. Faculty of Agriculture, Ain Shams University.

${ }^{2}$ lecturer of Agric. Eng. Dept. Faculty of Agriculture, Ain Shams University.

${ }^{3}$ Prof. Emerit. of Bio - Engineering. Dept., Agric. Eng. Res. Inst (AEnRI)., ARC.

${ }^{4}$ M.Sc. student of Bio - Engineering. Dept., Agric. Eng. Res. Inst (AEnRI), ARC.
} 
- $\quad$ There are overflowing $P V$ power from $0-1.125 \mathrm{~kW}$ from 10 am to 16 pm and less than $1.2 \mathrm{~kW}$ non-use before 10 am and after $16 \mathrm{pm}$. In this period can be used this power in another useful working.

Keywords: Solar Energy, photovoltaic, Milling Machine, Maize, Dry Bread, productivity.

\section{INTRODUCTION}

$\mathrm{E}$ gypt is suffering from shortage of traditional energy as (fuel diesel, gasoline and coal). The budget of supporting the traditional energy is very high. Now the price of fuel is increasing and the available of it is decreasing that cause multiple problem in agriculture sector. Energy is one of the most basic and crucial elements upon which built on it the base of economy life in the nowadays. Energy is needed for daily tasks as homes, schools, hospitals, industries, farms and countless other places. In the present, Egypt is facing several problems for operating farm machinery, tractors, operating modern irrigation systems and light energy. All previous problems are depending on traditional energy.

The agriculture sector has (135090 agriculture tractors, 2007394 irrigation pumps, 71113 threshing machines and 25116 other different types of machines) according to (Agriculture Directorates - General Administration of Agricultural Statistics, 2016).

Smith et al. (2014) pointed out that the history of photovoltaic electricity generation over the past 40 years within the UK is consistent with modern ideas about the space allocated to protect the production of sustainable solar energy and its follow-up and persistence and identifies the appropriate space that grows through the ability to advertise innovation in Solar field.

The growing population and industrial growth in Egypt leads to a significant increase in the demand for energy products in all sectors (residential, transport and industrial), which affects the increase in the consumption of oil, gas and electricity. It was necessary to pay attention to solar energy (Nick, 2014),

Singh, B. and A. K. Mishra, (2015) explained that the system of pumping water through solar cells depends on the production of solar 
energy from these cells as well as the requirements of the pump of energy. For battery-powered systems, it is important to use good batteries and the electrical controls must be integrated to protect the batteries. He pointed out that the amount of water out of the solar pump is affected by the rate of water lifting, distance and diameter of the pipeline and the size of the pump used and the amount of energy available to the system and can increase the energy by adding more solar panels.

Markvart et al. , (2012) said that the conversion of PV energy in solar cells consists of two basic steps. First, the absorption of light generates an electron hole pair. The electron and the aperture are then separated by the structure of the electrons of the device to the negative end and the holes in the positive terminal and thus generate electricity.

Dash, P. K. and N. C. Gupta, (2015). states that the PV units are classified in the standard test case (STC) ie at 1000 watts per square meter, the temperature at $25^{\circ} \mathrm{C}$ and the solar spectrum of $1.5 \mathrm{~g}$. Actual output of PV The field module differs from its estimated output due to changing environmental conditions. The resulting decrease is due to temperature.

Egypt receives $80 \%$ of a solar radiation in excess of $2000 \mathrm{~kW} \cdot \mathrm{m}^{-2}$ per year and over $90 \%$ of its land area is available for use to exploit this resource. This makes the potential for solar thermal power generation in Egypt to be one of the best in Africa (Bugaje, 2006).

Yang et al., (2014) said that solar energy is the most important energy for all renewable energy types and is the most abundant permanent resource on earth compared to conventional energy. It is inexhaustible, clean, pollution-free. High cost is the most important disadvantages of solar energy as well as instability in its implementation such as natural conditions, season and geographical latitude and variables such as weather.

Photovoltaic are the process of converting sunlight directly into electricity by using solar cells. The first photovoltaic device was demonstrated in 1839 by Edmond Becquerel. Egypt currently faces several key challenges; the first of one is growing population growth in energy demand. The second is the need to secure energy production to meet the nation's development goals. fossil fuels is important to find 
ways of decreasing dependency on it due to fluctuating and increasing costs of energy derived from it and also, also an urgent need to reduce the $\mathrm{CO} 2$ emission that result from the use of fossil fuels (Crossley et al., 1966). Bread residues can be used as feed animals or breadcrumbs production. Bread is a leavened product obtained from fermentation of wheat flour sugars liberated from starch by the action of natural flour enzymes. Bread contains from $50 \%$ to $75 \%$ of water, and the remaining part is flour (14.5\% moisture, $13 \%$ proteins and $0.5 \%$ ashes) (Zanoni, et al (1993)). According to $100 \%$ flour, rest of the ingredients will be in following measurements like leavening agent yeast $2 \%$, sugarvestigations to improve its performance. 4\%, salt 2\% (Mondal and Data, 2008). The starch is a key component in bread dry weight so bread residues can be considered a suiTable alternative to chemicals production (Ebrahimi et al., 2008). The manufacturing, and evaluate the performance of manufactured a snacks machine from bakery residues under local conditions, The experimental results recommended to use the machine for the highest productivity $12.6 \mathrm{~kg} / \mathrm{h}$, and the efficiency from $50 \%$ to 93.3\% under the following condition: extracting drum speed of 2500rpm., clearance of $1 \mathrm{~mm}$, milling Sieves of $1 \mathrm{~mm}$ and 15 hammer number (Amira, 2017).

The main objectives of this study are:

1 - The use of solar energy as it is renewable energy to dry, clean, safe and available.

2- Reduce environmental pollution from other traditional energy sources.

3- Use solar energy to operate some small fixed machines such as grinding machine.

\section{MATERIALS AND METHODS}

\subsection{MATERIALS}

Sun light is used as the sustainable source of energy through the photovoltaic system which will be used to operate milling machine. This study was run at the faculty of pharmacy, Heliopolis University, Cairo. The experiments were run at summer season 2017. The main parts of study and experiments were as follow:

\subsubsection{Photovoltaic system (PV):}


Photovoltaic system (PV) for solar cell operating system is semiconductor devices that convert sunlight to direct electricity (current DC). It was consisting of three main parts as shown in Fig. (1).

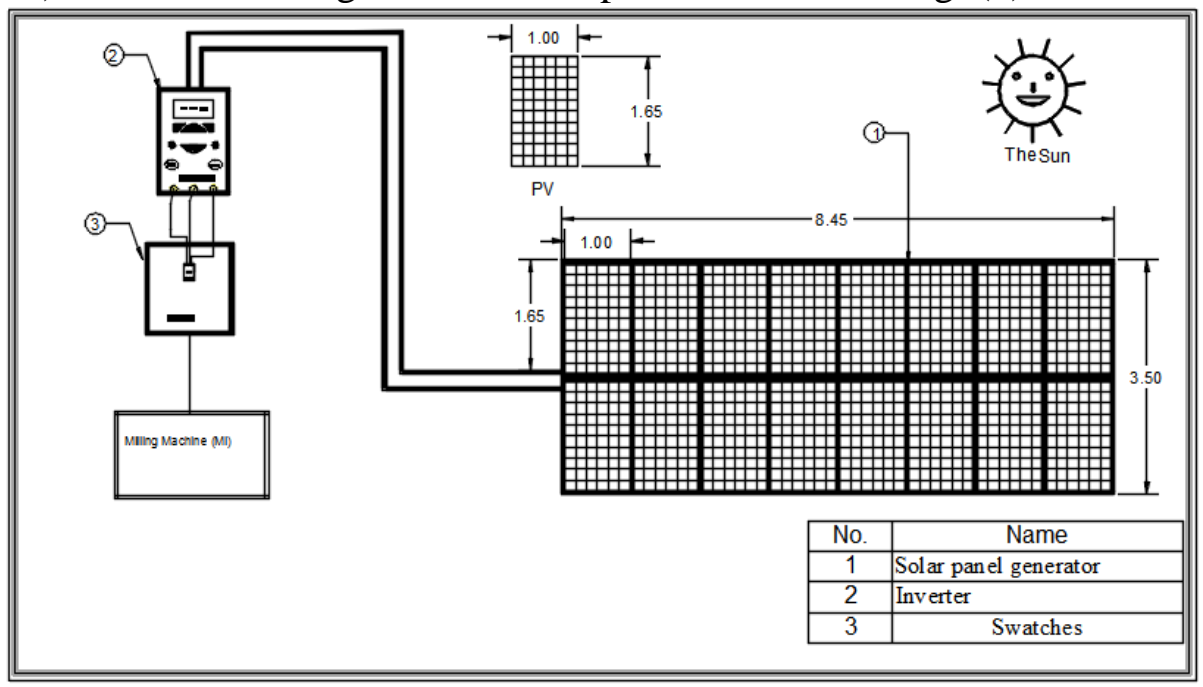

Figure (1): Photovoltaic system for solar cell operating system.

\section{Solar panel generator.}

Solar panel generator was consisting of 16 modules, which connected to each other respectively as shown in Figure (2). Each module is consisting of 60 solar cells. The code number of module is (XP 60/156-250 E35). Solar Panel is used to generate the energy that needed to operate milling machine. Solar panel specification was as shown in Table (1). It is concept to generate electric energy by using solar cells to convert solar energy to direct electricity - current (DC). The photons of light excite the electrons which generate a higher energy state to generate a create electricity.

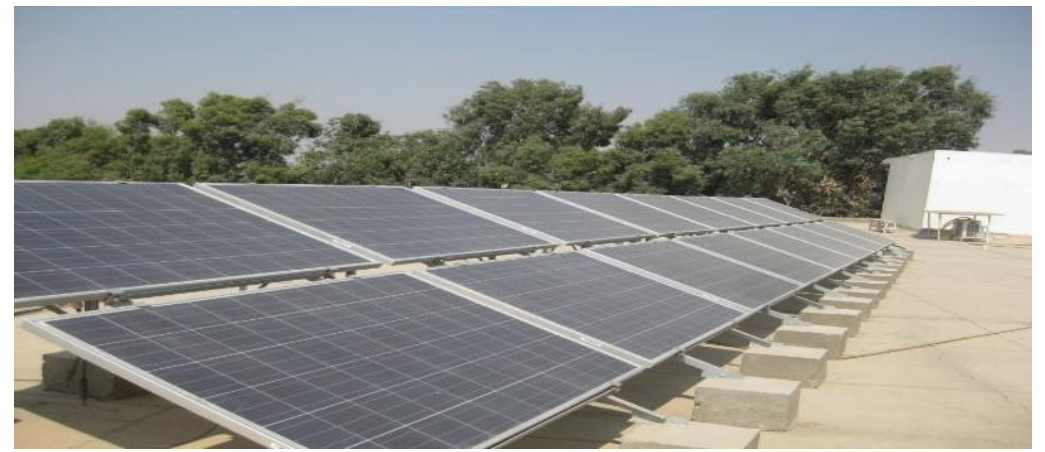

Figure (2): Solar panel generator. 
Table (1): Solar panel specification.

\begin{tabular}{|l|l|}
\hline Solar cell (mm) & $156 \times 199$ \\
\hline Number of cells per one module & $60(6 \times 10)$ \\
\hline Dimensions $(\mathrm{mm})$ & $1650 \times 990 \times 35$ \\
\hline Mass $(\mathrm{kg})$ & 18.6 \\
\hline Module Efficiency $(\%)$ & $11-15.3$ \\
\hline Operating Temperature $\left({ }^{\circ} \mathrm{C}\right)$ & From -40 to +85 \\
\hline Current at Pmax (A) & 6.67 \\
\hline Voc (V) & 34.9 \\
\hline
\end{tabular}

Solar cell is structuring from main parts as shown in Figure (3):

- Semiconductors like silicon. The basic assembly of a typical solar cell has negative current (n), positive current (p) and (n - P) as layers. Negative were injected between $n$ and $p$ layers. This setup was flanked by a front and a back contact.

- A glass cover was placed on top of the cell to provide protection from the environment.

The cells are connected together electrically to form photovoltaic modules, or solar panels. Which convert the sun light to the electricity. This process is called "photovoltaic effect".

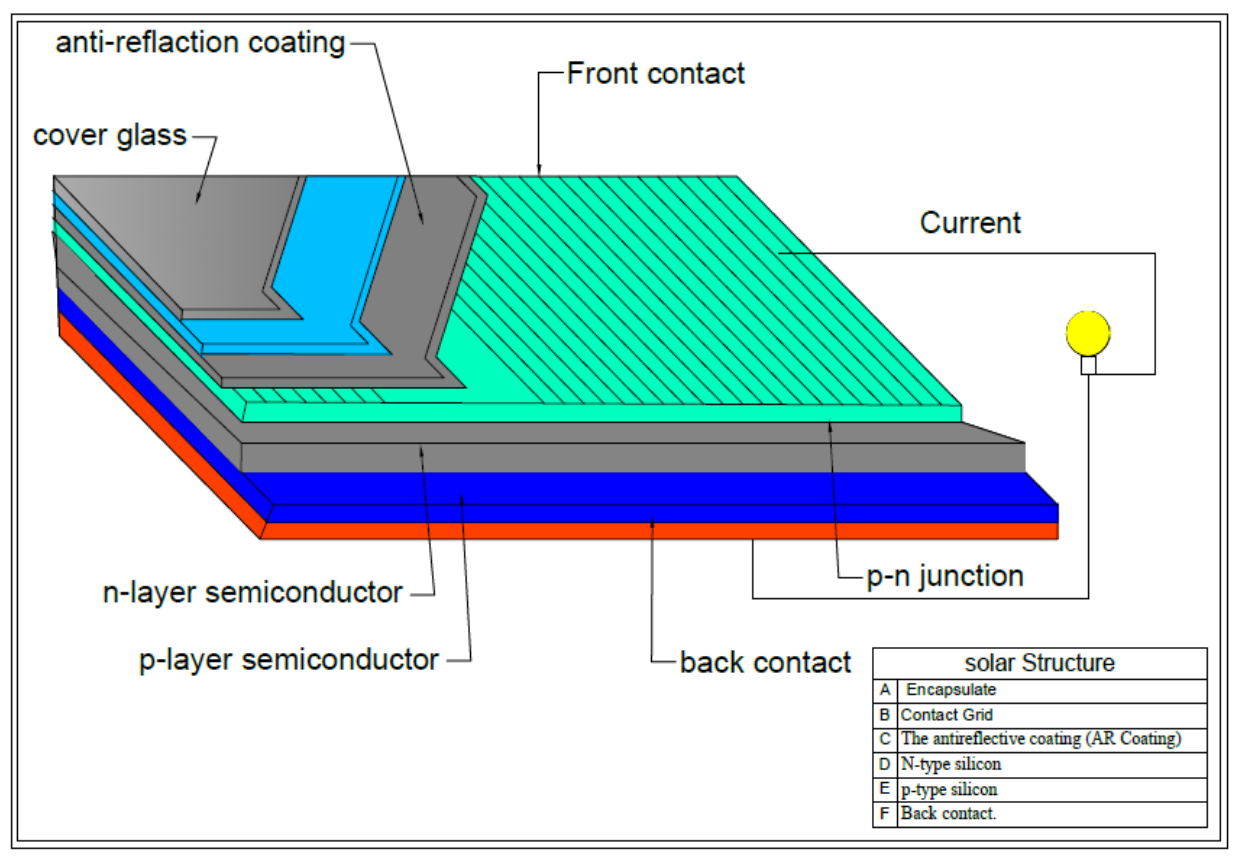

Figure (3): Structuring of a solar cell illustrating its theory of working. 


\section{Inverter (photovoltaic transport powered).}

The model of inverter is ACS355. This process is turning the direct current (DC) which generated from photovoltaic to alternating current (AC) which suiTable with electric motor that used with experiments as shown in, Figure (4). The current DC was turning to current AC through three steps as follow and as shown in Figure (5):

A- The rectifier converts the AC voltage (three-phase) to DC voltage.

B- The capacitor bank of the intermediate circuit stabilizes the DC voltage.

C- The inverter converts the DC voltage back to AC voltage for machine motor as shown in Figure (4).

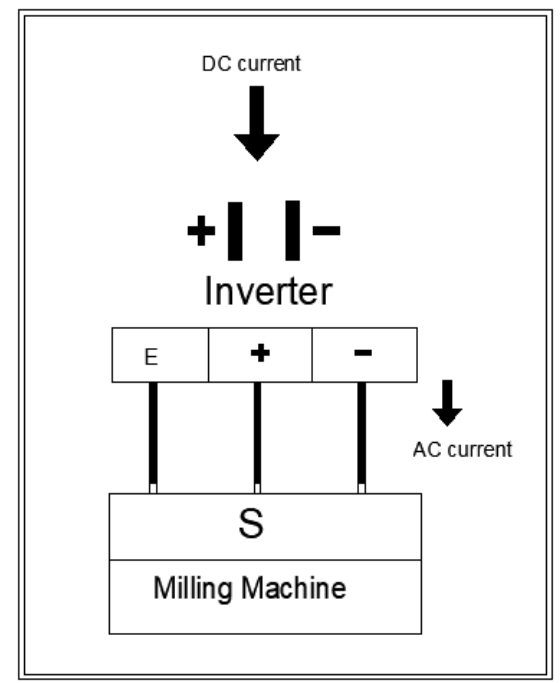

Figure (4): Inverter model ACS355

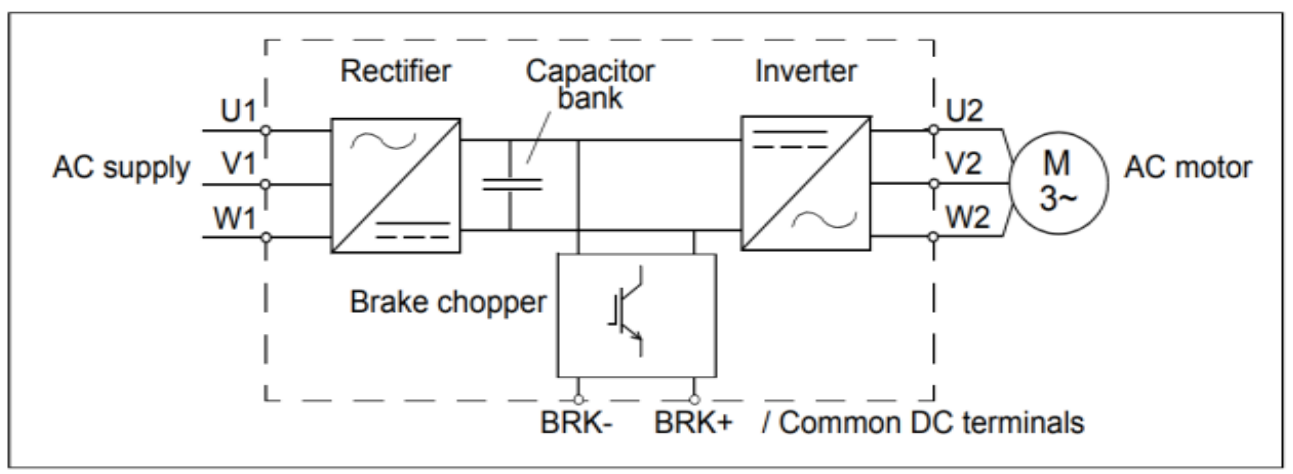

Figure (5): Main circuit diagram of the inverter. 


\section{Switch.}

It is used to operate the milling machine. The switch type is three phase and their specification was switch type (HAGER), maximum ampere output $63 \mathrm{~A}$ and Maxie volt output $(380-415 \mathrm{~V})$.it was as shown in Figure (6).

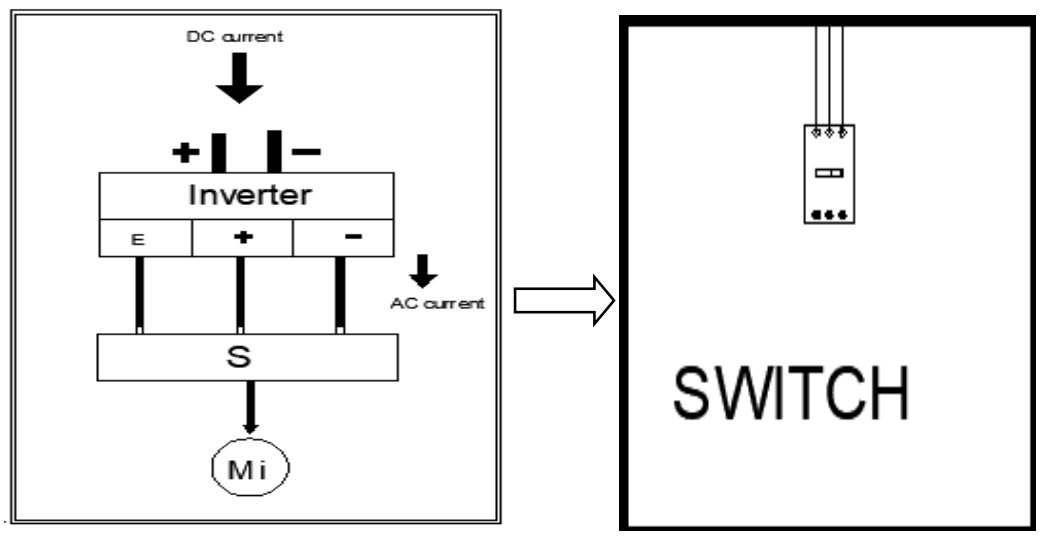

Figure (6): Shows the exit system from inverter to switch.

\subsubsection{Milling machine:}

In this study, milling machine is used to operate by solar energy. It was consisted of main frame, dram, plate feed hopper, milling chamber, concave, pulleys, belt and motor as shown in Figures (7 and 8) and Table (2).The milling machine designed by (Amira, 2017).

Table (2): The specifications of milling machine.

\begin{tabular}{|l|l|l|}
\hline No. & Items & Specification \\
\hline 1. & Type of hammer mill & Swinging hammer mill \\
\hline 2. & Hopper capacity & $3 \mathrm{~kg}$ \\
\hline 3. & Overall length & $550 \mathrm{~mm}$ \\
\hline 4. & Power & Electrical Motor $(\mathrm{AC}-$ three phase, $3.2 \mathrm{~A}, 1.5 \mathrm{~kW})$ \\
\hline
\end{tabular}

\subsubsection{The raw materials were used in this study:}

Two raw materials were used in experiments with small farm machine and with photovoltaic system as the source of power to operate grain yellow maize (M) and dry wheat bread (D).

Dry wheat bread It has been collecting from bakeries residues, the bread contains $(64 \%$ of flour, $14.5 \%$ moisture content, $13 \%$ proteins, $0.5 \%$ ashes yeast $2 \%$, sugar $4 \%$ and salt $2 \%$. 

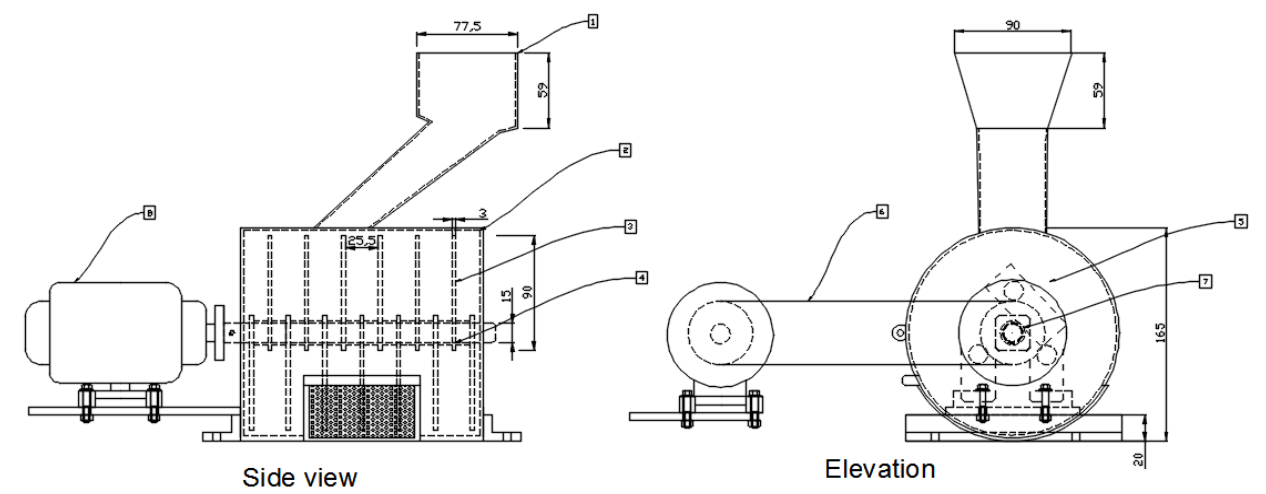

Dim in (mm)
(1) Frame,
(2) Dram,
(3) Plate feed hopper,
(4) Milling chamber,
(5) Concave,
(6) Pulleys,
(7) Belt
(8) Motor.

Figure (7): Hammer mill prototype
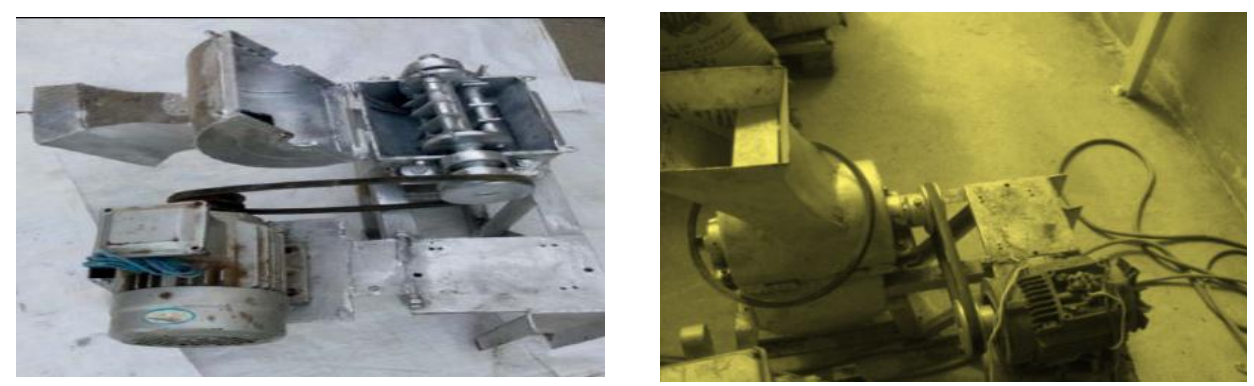

Figure (8): Hammer mill photograph.

\subsubsection{Instruments and Measurements:}

Instruments and measuring devices will be used to run experiments in this study as follows:

- Portable electronic scale was ranged from $(0-45 \mathrm{~kg})$, with accuracy $10 \mathrm{~g}$ and batteries 2AAA.

- Digital force gauge was used to measure hardness for raw materials by different force units (N, IP and kg).

- Electric oven: "model (655F Cat. No. 13-245-655), temperature range $\left(50\right.$ to $\left.300^{\circ} \mathrm{C}\right)$, power source electricity, with accuracy $50^{\circ} \mathrm{C}$, origin of manufacture Canada" was used to dry raw materials for calculate the moisture content.

- Digital stop watch: "Type: Casio JHS-20", with accuracy 1/100 second). 


\subsection{Methods:}

Photovoltaic system has been used to receive sunlight and transform it into energy that will be used to operate milling machine. Some measurements and calculations were run on the photovoltaic system to measure the possibility to convert the solar energy to an electric energy which used to operate milling machine Several experiments have been conducted in this study to test the possibility of using solar energy to operate milling machine with maize and dry bread. Power PV system $\left(\mathrm{P}_{\mathrm{pv}}\right)$ output direct, Power $(\mathrm{P})$ and productivity $\left(\mathrm{P}_{\mathrm{r}}\right)$ and calculated during operate milling machine with yellow maize and dry bread each separately as follows:

\subsubsection{Solar Radiation (SR):}

Solar radiation was measured and recorded daily from 9 am to $17 \mathrm{pm}$ throw August and September 2017. It was carried out through the Central Laboratory for Climate - Agricultural Research Center. The data of solar radiation were recorded per each hour during the day from 9 am to 17 pm.

\subsubsection{Current measurement (I):}

The current requirement for operating milling machine in this study was measured by the interferometer instrument which connected with the photovoltaic system. Photovoltaic system was getting out 380 to 400 volt which suitable for operating milling machine during the experiments. The angle of cells was 30 degree on the latitude south that suitable for experiments location and can help to receive as much as possible from solar radiation. The interferometer is measuring and recording the consumption of the current for each process.

\subsection{3: Power $P V$ system $\left(P_{p v}\right)$ according solar radiation.}

It is possible to calculate the power generate from PV system $\left(\mathrm{P}_{\mathrm{pv}}\right)$ according equation (1).

\section{Where:}

$$
\mathbf{P}_{\mathbf{p v}}=\mathbf{S R} \cdot \mathbf{A}_{\mathrm{pv} \cdot} \eta_{\mathrm{pv}}
$$

$\mathrm{P}_{\mathrm{pv}}=$ Power of PV system $(\mathrm{W}), \mathrm{SR}=$ Solar Radiation $\left(\mathrm{W} \cdot \mathrm{m}^{-2}\right)$, $\mathrm{A}_{\mathrm{pv}}=$ Area of solar module $\left(\mathrm{m}^{2}\right)$ and $\eta_{\mathrm{pv}}=$ efficiency of solar module, it's ranged from $11-15.3 \%$, from data specifications. 
The actual efficiency $\left(\eta_{\text {actual }}\right)$ can be calculated from actual power $\left(\mathrm{P}_{\text {actual }}\right)$ as follows:

$$
\eta_{\text {actual }}=\frac{P_{\text {actual }}}{S R \times A_{p v}} * 100 \ldots \ldots \ldots \ldots \ldots(1 a)
$$

Table (3): Parameter of the actual efficiency.

\begin{tabular}{|c|c|c|c|}
\hline$P_{\text {actual }}$ (watt) & SR $\left(\right.$ W.m $\left.{ }^{-2}\right)$ & $\mathrm{A}_{\mathrm{pv}}\left(\mathrm{m}^{-2}\right)$ & $\eta_{\text {actual }} \%$ \\
\hline 2700 & 788 & 26 & 13.17 \\
\hline 2650 & 771 & 26 & 13.21 \\
\hline 2700 & 788 & 26 & 13.17 \\
\hline
\end{tabular}

$$
\eta_{\text {mean }}=\frac{\sum_{0}^{n} \eta_{\text {actual }}}{n}
$$

Where: $n$ : number of readings.

$$
\therefore \eta_{\text {mean }}=13.18 \%
$$

\subsection{4: Power consumption (P):}

It was calculated for milling machine with each of maize seed and bread according (Kurt, 1979), equation (2).

\section{Where:}

$$
\mathrm{P}=\frac{\sqrt{3} I \cdot V \eta \cos \Theta}{1000}
$$

P: Power consumption, I: Line current strength (Amperes), V:

Potential strength (voltage) measurement, $\cos \Theta$ : power factor (being equal to 0.84 ), $\eta$ : Mechanical efficiency assumed (85\%) and $\sqrt{3}$ : constant of three phase engine $=1.732$.

\subsubsection{The productivity $(\mathrm{Pr})$.}

It was calculated for milling machine which operated by PV system for each of two material (maize and dry bread). All experiments were run at different durations during the day. It was calculated by units' $\mathrm{kg}$ per hours according equation (3).

$$
\text { Productivity }\left(\mathrm{P}_{\mathrm{r}}\right)=\text { weight }(\mathrm{m}) / \mathrm{time}(\mathrm{t}) \quad\left(\mathrm{kg} \cdot \mathrm{h}^{-1}\right)
$$

\section{RESULTS AND DISCUSSION.}

The solar photovoltaic system was used in this study to evaluate small farm machinery (Milling machine). Data and measurements were 
collected to analysis and evaluate the performance, efficiencies and power consumption.

The Experiments and tests were carried out on the small farm machinery by using the power that derived from the solar cell system. The tests results were taken at randomly days from August and September 2017 and the results were taken every hour start from 9 am to $17 \mathrm{pm}$. The final results were as follows:

\subsection{Physical and mechanical properties of raw material.}

The physical and mechanical properties were resulted from tests and analysis for each of maize and dry bread as shown in Table (4).

Table (4): Physical and mechanical properties for each of maize and dry bead.

\begin{tabular}{|l|l|l|}
\hline Raw material & Maize & Dry bread \\
\hline Variety & Giza 162 & Wheat \\
\hline Moisture content, \% & 10 & 13 \\
\hline Hardness, N & 150 & 50 \\
\hline
\end{tabular}

\subsection{Power $(\mathrm{kW})$ :}

\section{A. Power of PV system (kW) according to solar radiation:}

Solar radiation was increasing gradually from sunrise till reached to the maximum value at the noon, and then it was decreased gradually until it reaches the minimum value at sunset. The variation in solar radiation was affected on the power that generate from photovoltaic system. This power was calculated by equation (1) according solar radiation. The solar radiations was ranged from 469 to $807 \mathrm{~W} \mathrm{~m}^{-2}$ at every hour during the day from 9 am to $17 \mathrm{pm}$, also the results of power was 1.8 to $2.5 \mathrm{~kW}$, The maximum power was at 12 clocks to 1 clock pm as shown in Figure (9).

\section{B. power consumption $(\mathrm{kW})$ :}

The solar photovoltaic system was used in this study to evaluate milling. It was measured and calculated for milling machine which operated with each of maize and dry bread. The current intensity and voltage which produced from the PV system were measured directly by using inverter device. Equation (3) was used to calculate the power consumption. The results of power consumption were as follows: 

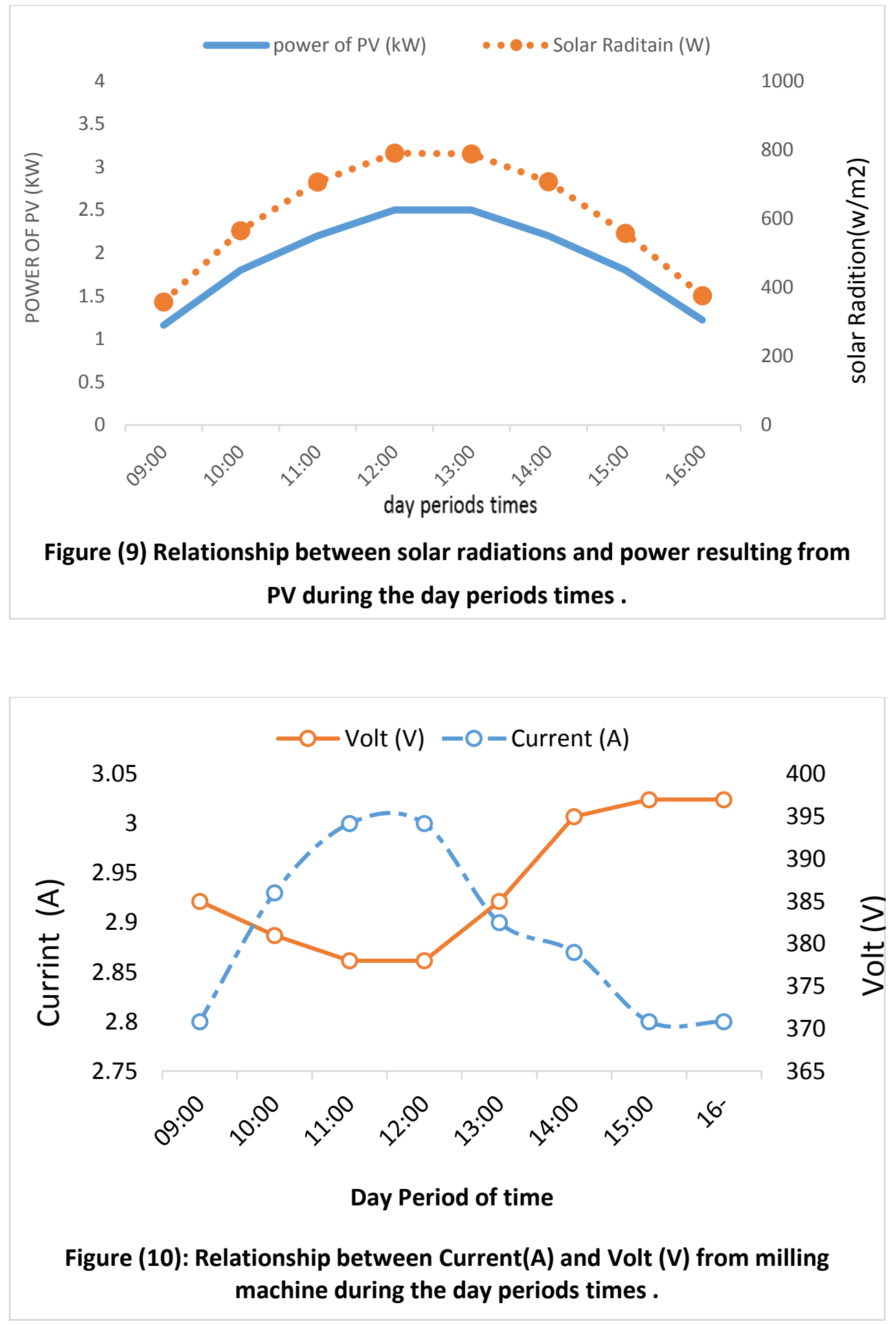

Misr J. Ag. Eng., April 2019 


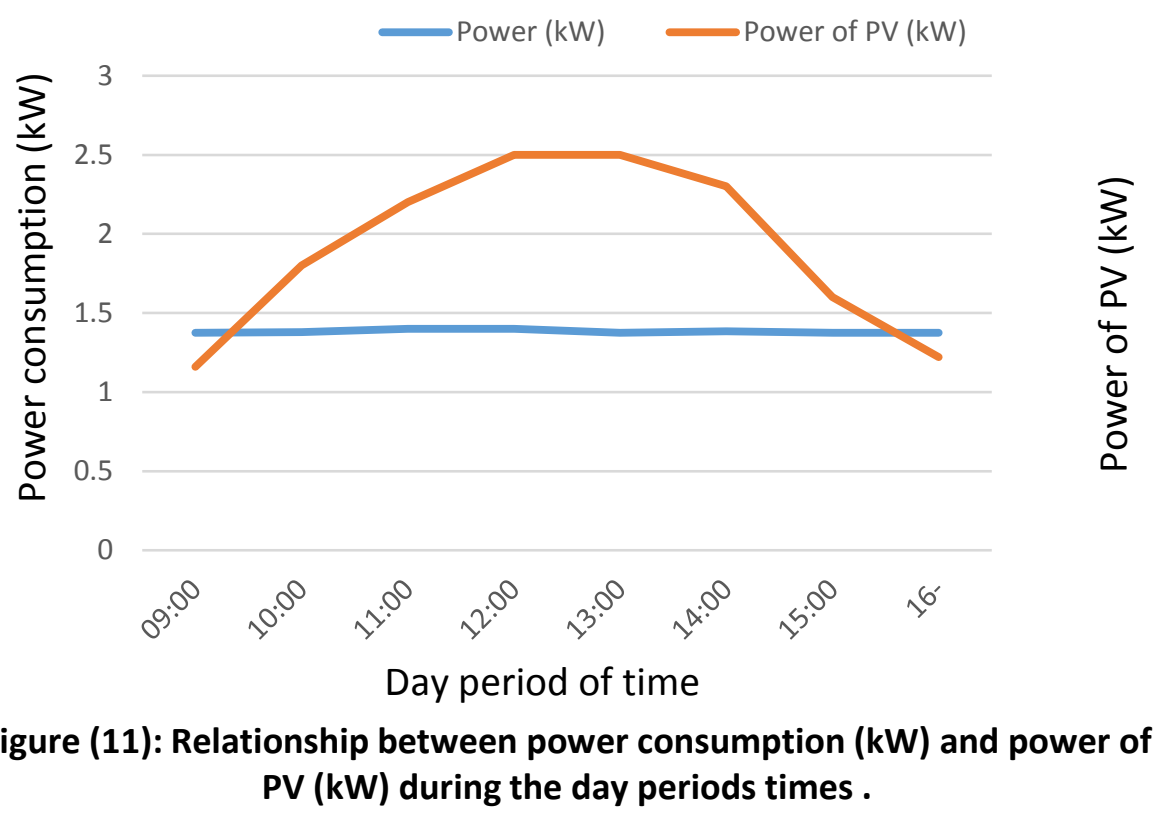

With Maize: The power consumption for milling the maize was ranged from 1.37 to $1.4 \mathrm{~kW}$ (AC motor) at day period time from 9 am to $17 \mathrm{pm}$. Note, that when the current intensity increased the voltage was decreasing (inverse relationship), as shown in Figure (10). Also, the power consumed for milling maize is almost cons at different period's times and the difference is resulting due to a slight difference of rotational speed of the motor which resulted from a slight difference in the voltage and thus difference of rotational speed of the milling. The difference of power consumptions was about $0.03 \mathrm{~kW}$ as shown in Figure (11). The power from PV system was not enough to turn milling machine and mill maize that before 9 o'clock morning and after 17 o'clock afternoon.

With Dry Bread: The power consumption for milling the dry brad was $1.37 \mathrm{~kW}$ at periods time from 9 am to $17 \mathrm{pm}$. The relationship between current intensity and voltage is (inverse relationship), as shown in Figure (12). The power consumptions shown in Figure (13). The power from PV system was not enough to turn milling machine and mill dry bread that before 9 o'clock morning and 17 o'clock afternoon. 

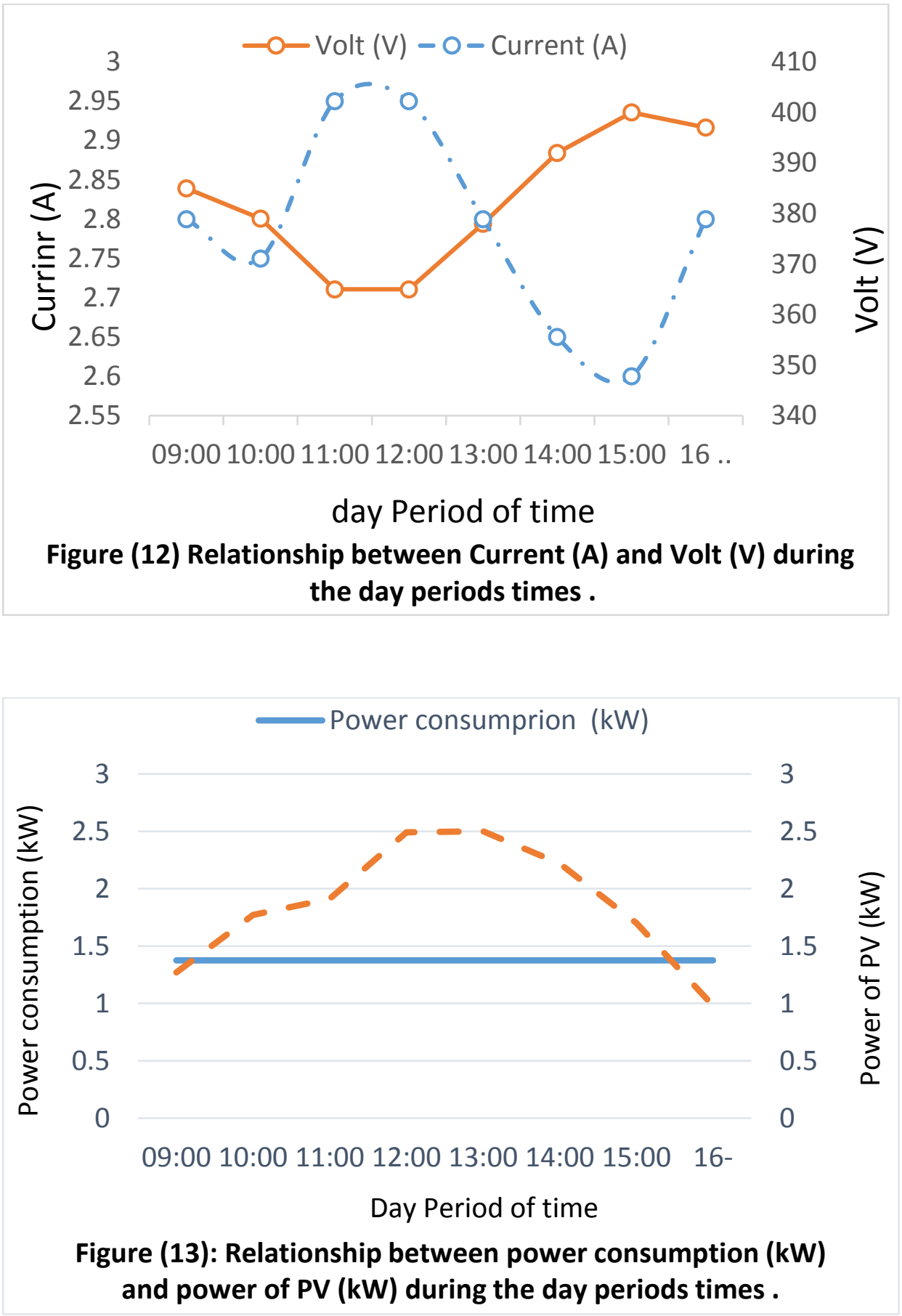


\section{D- Productivity $\left(\mathbf{P}_{\mathbf{r}}\right)$ :}

Figure (14), (15) shows the productivity curve for maize and dry bread, through the curves can be observed as follows:

\section{There are three stages:}

- Frist stage: The productivity equal zero, because the electric AC motor does not work (before 10 o'clock, the PV power was not enough).

- Second stage: The productivity is almost constant:

○ Fluctuated from $8.67-9.09 \mathrm{~kg} / \mathrm{h}$ and $7.353-7.936 \mathrm{~kg} / \mathrm{h}$ for maize and dry bread respectively,

- The deference between maximum and minimum productivity was $0.42 \mathrm{~kg} / \mathrm{h}$ and $0.583 \mathrm{~kg} / \mathrm{h}$, with the deference ratio $4.62 \%$ and $7.35 \%$ for maize and dry bread respectively,

$\circ$ The maximum value of productivity at period $12-13 \mathrm{pm}$,

- Third stage: The productivity equal zero, because the electric AC motor does not work (after 16 o'clock, the PV power was not enough).

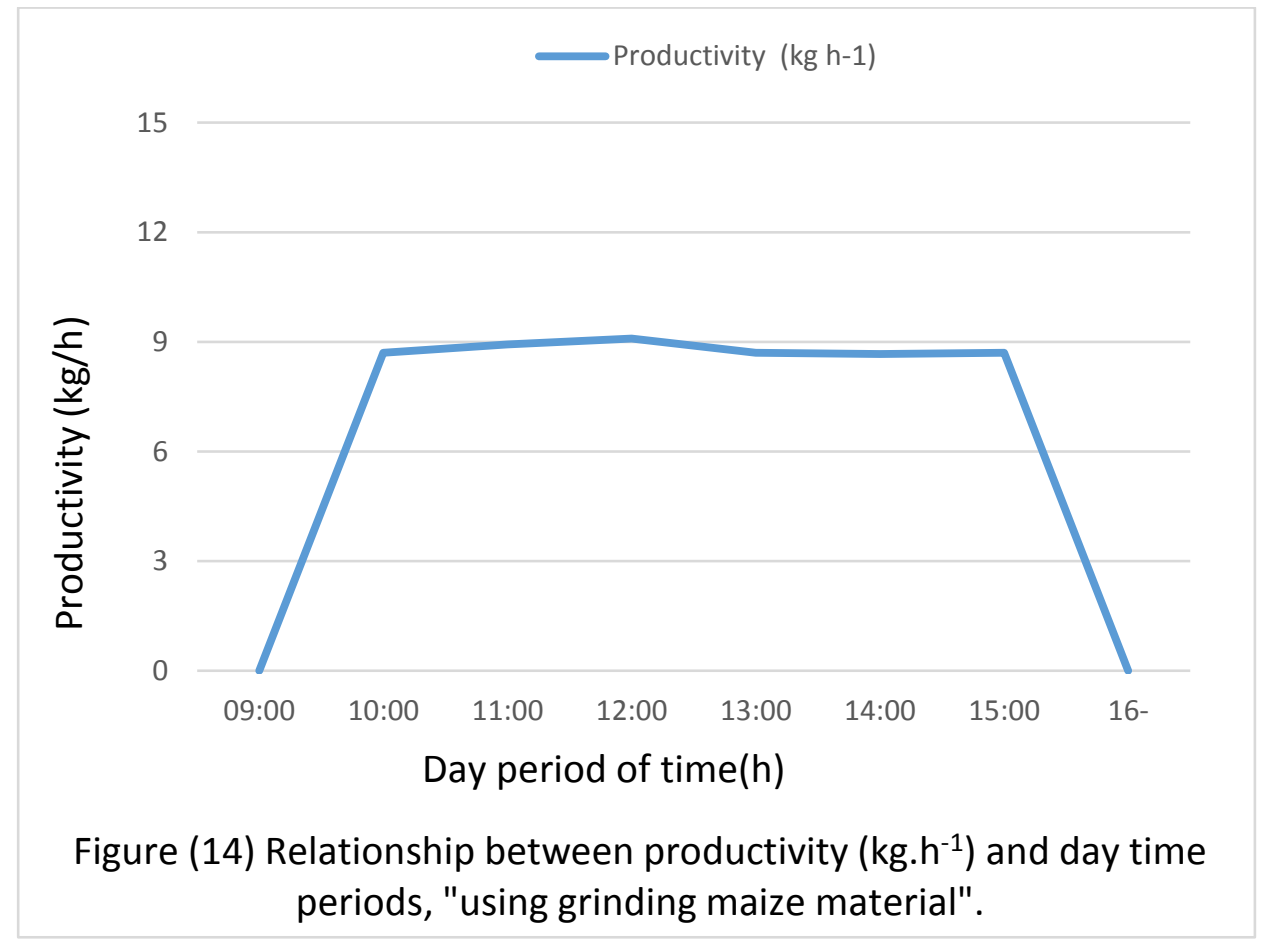




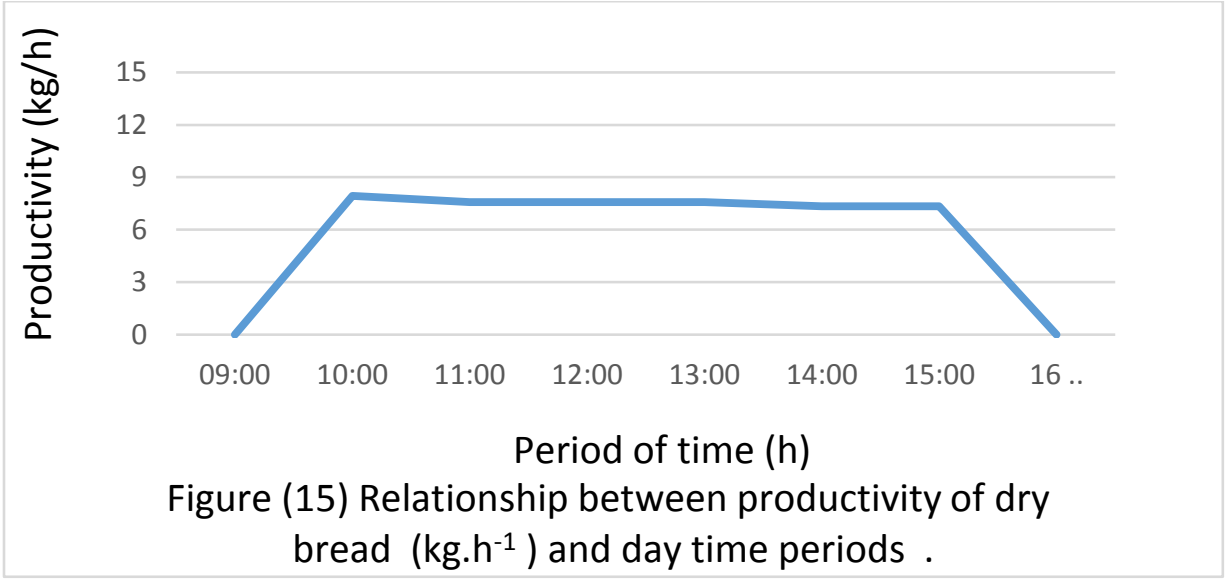

\section{CONCLUSIONS AND RECOMMENDATIONS}

- Solar energy in Egypt is an abundant source of energy available throughout the year, so this energy can be exploited in the operation of fixed agricultural machinery, which will save from the consumption of conventional fuel.

- In this study, the milling machine was operated by using solar energy through PV system.

- The power which generated from PV system was enough to operate milling machine from 10 am to $16 \mathrm{pm}$ to mill maize and dry bread.

- The power before $10 \mathrm{am}$ and after $16 \mathrm{pm}$ was not enough to operate milling machine.

- There are overflowing PV power from $0-1.125 \mathrm{~kW}$ from 10 am to 16 $\mathrm{pm}$ and less than $1.2 \mathrm{~kW}$ non-use before 10 am and after $16 \mathrm{pm}$. In this period can be used this power in anther useful working (adding to Government Electricity Network, storing in charging battery, small machine ...).

- The maximum productivities with maize and dry bread were $9.09 \mathrm{~kg} / \mathrm{h}$ and $7.5 \mathrm{~kg} / \mathrm{h}$ respectively.

\section{REFERENCES}

AlNaser, N.W.; Dakhel, A.A.; Al Othman, M.J.; Batarseh, I.; Lee, J.K.; Najmaii, S.;. (2015), Dust Accumulation Study on the Bapco 0.5 MWp PV Project at University of Bahrain. Int. J. Power Renew. Energy Syst, 2, 38-54.

Agriculture Directorates Egypt - General Administration of Agricultural Statistics (2016), publisher by Economic Affairs sector. 
Amira, M., (2017). "manufacturing snacks production unit utilizing bakeries residues" PHD. Agric. (Agricultural Engineering), Fac. of Agric., Zagazig Univ, No. of pages: $141 \mathrm{p}$.

Mondal A. and A.K. Datta (2008). Bread baking - a review, J. Food Eng., 86 465-474.

Bevirt, W. David, (1984) (Environmental Systems Technology) Published by National Environmental Balancing Bureau, Vienna.

Bugaje, I. M., (2006), Renewable energy for sustainable development in Africa: a review. Renewable and sustainable Energy Reviews, 10: $603-612$.

Crossley, P.A., Noel, G.T. \& Wolf, M. (1966), Review and Evaluation of Past Solar - Cell Development Efforts, Report by RCA AstroElectronics Division for NASA, Contract Number NASW-1427, Washington, DC, No. of pages: $29 \mathrm{p}$.

Dash, P. K. and N. C. Gupta, (2015). Effect of Temperature on Power Output from Different Commercially Available Photovoltaic Modules. International Journal of Engineering Research and Application; 5(1): 148 -15.

Ebrahimi, F., M. Khanahmadi, S. Roodpeyma and M.J. Taherzadeh, (2008). Ethanol production from bread of residues, Biomass Bioenergy 333-337.

Markvart, T. and L. Castaner, (2012). Principles of Solar Cell Operation In: Mcevoy, A., T. Markvart, L, Castaner, (cds) Practical Handbook of Photovoltaics. 2nd cd. Elsevier Science Ltd: Oxford Uk; 7 - 30.

Nick, B. (2014). "Egypt's looming energy crisis," Financial Times, last checked online at:http://blogs.ft.com/nickbutler/2014/08/03/egpts-looming-energy-crisis/.

Singh, B. and A. K. Mishra, (2015). Utilization of solar Energy for Driving a Water Pumping System. International Research Journal of Engineering and Technology (IRJET); 2(3): 1 - 5.

Smith, A.; Kern, F.; Raven, R. and Verhees, B., (2014). Spaces for sustainable innovation: Solar photovoltaic electricity in the UK, Technological Forecasting \& Social Change, (81):115130 
Kurt, G. (1979). Engineering formulas. $3^{\text {rd }}$. Ed. Mc Graw - Hill book Co-580 pages; Publisher: McGraw-Hill Education;8 edition (1 July 2006).

Radziemska, E, K., (2015), Degradation of electrical performance of a crystalline photovoltaic module due to dust deposition in northern Poland, Renewable Energy (78):418-426.

Yang, L.; He, B. J. and Ye, M., 2014. The application of solar technologies in building energy efficiency:BISE design in solarpowered residential building, Technology in Society 38: 111-118.

Zanoni B. and C. Peri (1993). A study of the bread-baking process. I: A phenomenological model, J. Food Eng. 19 (4) 389-398.

\section{الملخص العربى \\ إستخدام الطاقة الثمسية لتشغيل آلة طحن}

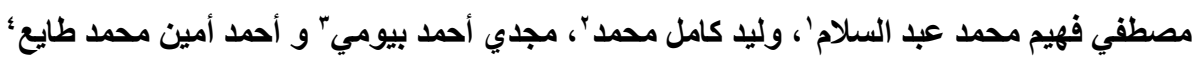
استخدام الطاقة الثمسية تساعد فى حل جزء من المشكلة الرئيسية للطاقة التقليدية في مصر

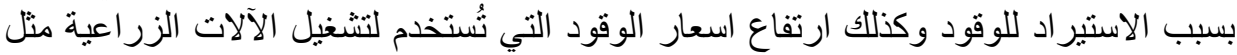

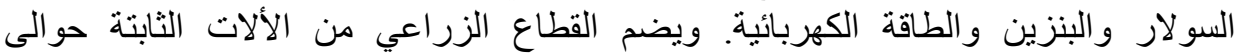

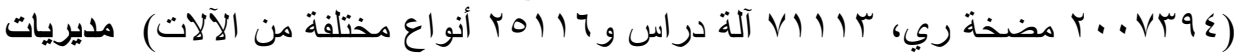

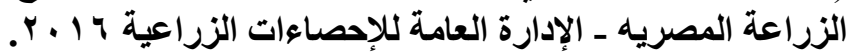

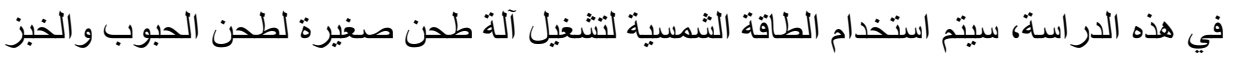
الجاف لإستخدامه كمصدر للأعلاف. وحيث أن مصر هي إحدى الدول التي تقع في منطقة

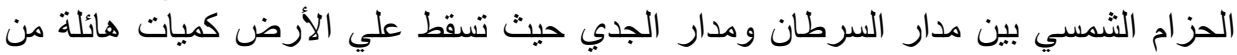

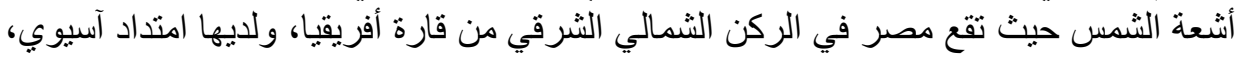

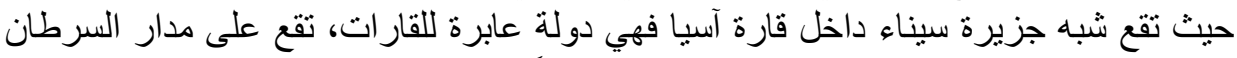

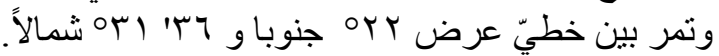

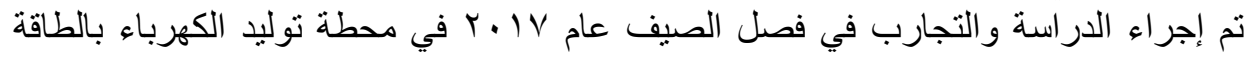
الشمسية بجامعة هليوبوليس بالقاهرة. وتم استخدم ضوء الثمس كمصدر فيتدام للطاقة في هذه

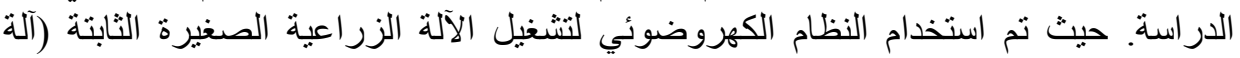
الطحن) حيث ان النظام الكهروضوئي (PV) هو أحد أجهزة أشباه الموصلات التي تحول ضوضئ

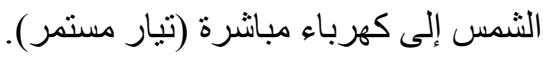
و يتكون النظام من ثناثة أجز اء رئيسية:

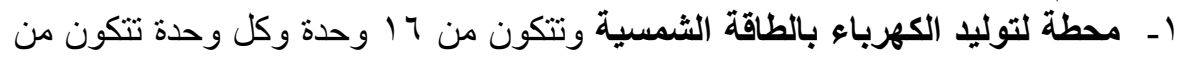

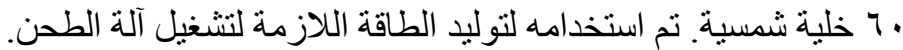

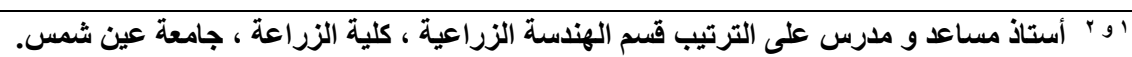

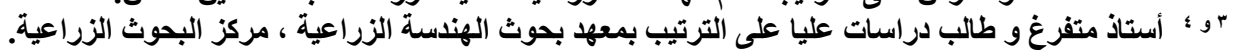


r- محول التيار (Inverter) ويقوم بتحويل التيار المستمر DC المتولد من الخلايا

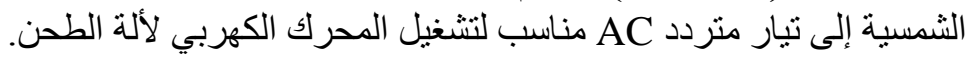

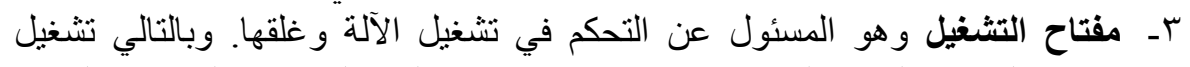
ماكينة الطحن بالطاقة الثمسية في فترات زمنية الثية مختلفة على مدار اليوم من الساعة

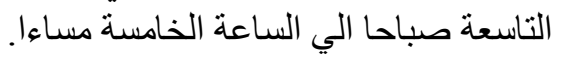

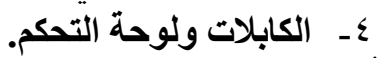

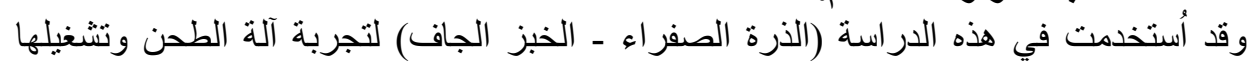

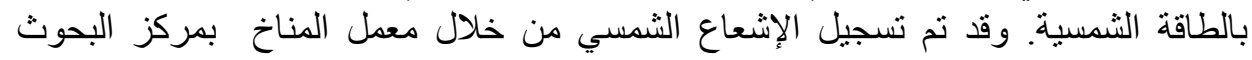

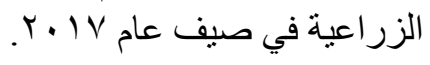

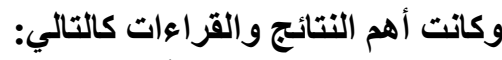

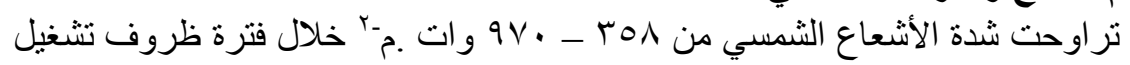

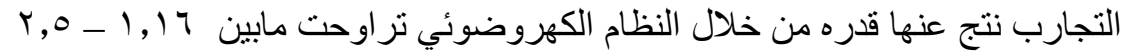

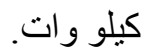

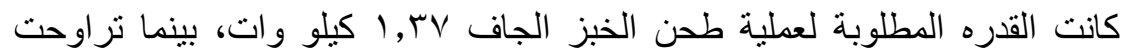

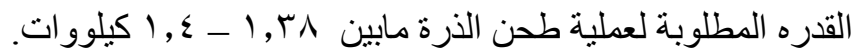

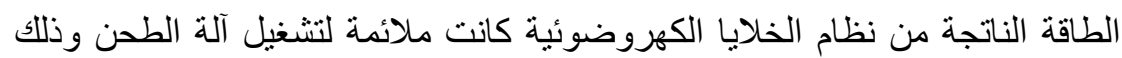

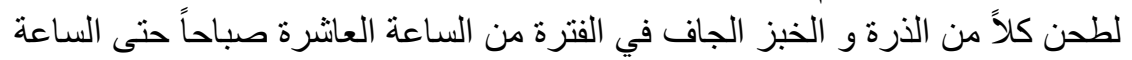

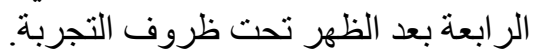

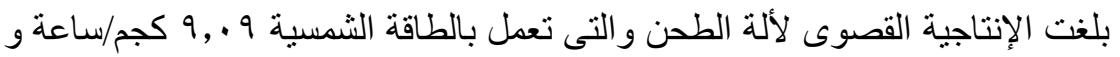

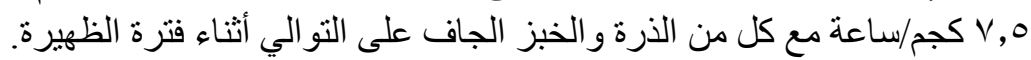

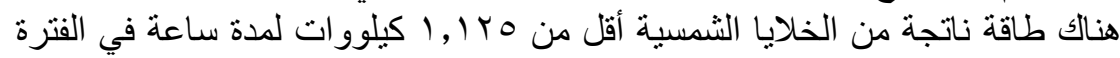

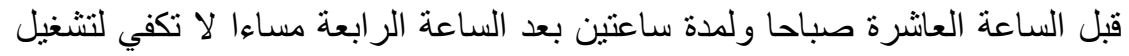

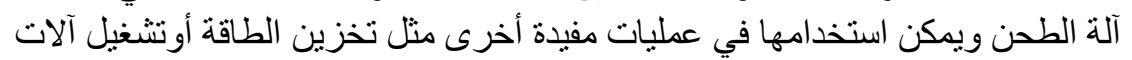
لها متطلبات قدرة أقل من طاقة الطحن وتناسب هذئ هذه الألات.

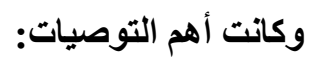

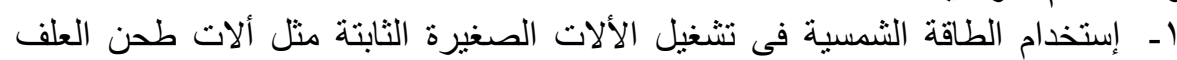

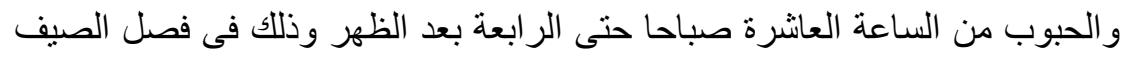

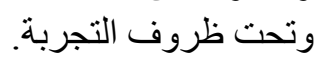
r- الإهتمام بتصنيع الخلايا الثمسية وزيادة انتاجها مما يقلل من تكاليفها ويزيد من انتشار ها.

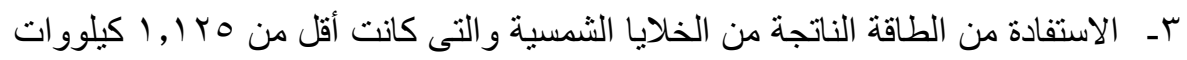

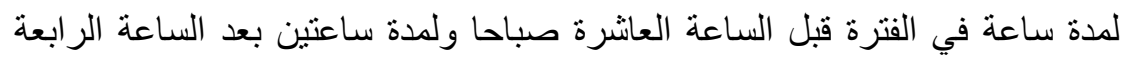

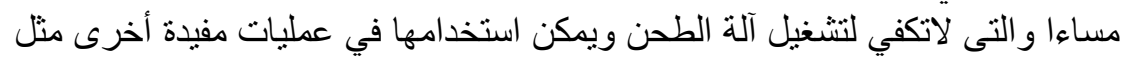
تخزين الطاقة أوتشغيل آلات لها متطلبات قدرة أقل من طاقة الطحن وتناسب هذه الالات. عـ - تزويد القرى بمحطات للطاقة الثمسية لتشجيع الفلاح على استخدامها و اقتناعه بها عند تشغيلها فى محطات الارشاد. 